American Journal of Animal and Veterinary Sciences 7 (1): 16-20, 2012

ISSN 1557-4555

C 2012 Science Publications

\title{
Levamisole Enhances Cell-Mediated Immune Responses and Reduces Shedding of H9N2 Avian Influenza Virus in Japanese Quails (Coturnix coturnix japonica)
}

\author{
${ }^{1}$ Tahoora Shomali, ${ }^{2}$ Najmeh Mosleh and ${ }^{2}$ Arash Alaeddini \\ ${ }^{1}$ Department of Basic Sciences, Division of Pharmacology and Toxicology, \\ ${ }^{2}$ Department of Avian Medicine, \\ School of Veterinary Medicine, Shiraz University, Shiraz, Iran
}

\begin{abstract}
Problem statement: Regarding the role of Japanese quails (Coturnix coturnix japonica) in reassortment and spreading of avian influenza (AI) viruses and inadequate protection of vaccination in this species, the present study aimed to evaluate the effect of levamisole as an immunomodulatory agent on cell-mediated immunity (CMI), antibody responses and shedding of H9N2 AI virus in experimentally infected quails. Approach: On day 20 of age, 100 quails randomly allocated into 4 equal groups. Birds in groups 2, 3 and 4 were inoculated with virus where group 1 kept as control. Groups 3 and 4 orally received $15 \mathrm{mg} \mathrm{kg}^{-1}$ levamisole for three consecutive days just before virus inoculation which was repeated 10 days post inoculation (PI) only in group 4. Antibody titers and CMI of all birds were assayed by HI and delayed type hypersensitivity (DTH) test respectively and virus detection in fecal and tracheal samples performed by RT-PCR method. Data analyzed by oneway ANOVA and Tukey's test. Results: Levamisole in both regimens had no appreciable effect on antibody titers $(\mathrm{p}>0.05)$ while repeated regimen resulted in higher CMI response than group 2 at 48 and $72 \mathrm{~h}$ post DTH test $(\mathrm{p}=0.011$ and $\mathrm{p}=0.031$ respectively). Total fecal samples positive for virus from birds in group 3 and 4 were 34.4 and $40 \%$ lower than group 2 respectively. For trachea, the positive samples were $33.3 \%$ (group 3) and $46.7 \%$ (group 4) lower than group 2. Moreover; fecal and tracheal samples from levamisole treated birds (especially from group 4) became void of virus earlier than group 2. Conclusion/Recommendations: Levamisole administration in a repeated regimen enhances CMI response against H9N2 AI virus and reduces virus shedding in quails. This may pave the road for further investigations on potential positive effects of this agent on prevention and management of H9N2 AI infections in quail industry.
\end{abstract}

Key words: Avian influenza, immunomodulation, quails

\section{INTRODUCTION}

H9N2 avian influenza (AI) viruses are among the most commonly occurring infections in domestic poultry populations and several epidemics of this subtype have been reported in Asia and North America since 1990 (Alexander, 2000; Peiris et al., 2001; Tang et al., 1998). In Iran, an outbreak of H9N2 AI viruses occurred in broiler chickens during 1998-2001 with a mortality rate of $20 \%$ to $60 \%$ in affected farms (Nili and Asasi, 2003). Although this subtype is considered as a low-pathogenicity AI virus, it can infect a wide variety of species including Japanese quails (Coturnix coturnix japonica). Ebrahimi et al. observed that a field-isolated H9N2 AI virus can infect all unvaccinated quails while infects $30 \%$ to $40 \%$ of birds vaccinated with inactivated vaccine, which indicates incomplete protection of this vaccine against AI viruses in quails. Interestingly, it has been shown that quails can provide an environment for the reassortments between avian and human influenza viruses and act as a potential intermediate host by carrying sialic acid receptors compatible with binding to avian and human influenza viruses (Wan and Perez, 2006).

Recently, manipulation of immune responses by various agents in order to improve efficacy of vaccination has been practiced. Immunostimulant agents such as levamisole have been used in an attempt to enhance protective immune responses of chickens for prevention or control of infectious diseases including Newcastle disease (Yin et al., 2007), infectious bursal disease (Singh and Dhawedkar, 1993), Marek's disease

Corresponding Author: Najmeh Mosleh, Department of Avian Medicine, School of Veterinary Medicine, Shiraz University, Shiraz, Iran. P.O. Box: 71345-1731, Tel: 0098 (711) 6138822, Fax: 0098 (711) 2286940. 
(Kodama et al., 1980) and coccidiosis (Onaga et al., 1984; Giambrone and Klesius, 1985) with various rates of success; however, to our knowledge the effect of this drug on immune responses and virus shedding period of H9N2 AI viruses in quails has not been addressed yet. Regarding to the growing interests in quail industry in Iran, inadequate efficiency of vaccination and the role of this species in reassortment and spreading of AI viruses, the present study was conducted to evaluate the effect of levamisole administered in two regimens on cell-mediated immunity (CMI), antibody responses and virus shedding period of $\mathrm{H} 9 \mathrm{~N} 2 \mathrm{AI}$ viruses in experimentally infected quails.

\section{MATERIALS AND METHODS}

H9N2 AI virus: The virus used for this study, A/chicken/Iran/772/1998 (H9N2), was obtained from Razi serum and vaccine research institute, Tehran, Iran. Virus was propagated in 10-day-old embryonated chicken eggs and stored at $-70^{\circ} \mathrm{C}$. Avian influenza a virus was titrated to determine the $50 \% \mathrm{Egg}$ Infectious Dose $\left(\mathrm{EID}_{50}\right)$ by the method of Reed and Muench (1937).

Animals and experimental design: One hundred oneweek-old Japanese quails from both sexes were purchased and randomly allocated into 4 equal groups $(n=25$ each). Birds had free access to feed and water and reared under bio security conditions. Maternal antibody titer against AI was assayed on the entrance day of birds by HI method. On day 20 of age, birds in groups 2, 3 and 4 were inoculated through the nares with a concentration of $10^{6.5}$ EID $_{50}$ /bird H9N2 AI viruses; while birds in group $1 \mathrm{kept}$ as control and received normal saline. Birds in groups 3 and 4 received $15 \mathrm{mg} / \mathrm{kg}$ levamisole (Razak Pharmaceutical Laboratories, Tehran, Iran) for three consecutive days just before virus inoculation (days 17, 18 and 19 of age) by oral gavages. This treatment was repeated 10 days post inoculation (PI) (days 30, 31 and 32 of age) only in birds of group 4 .

All methods used in the study were in compliance with the institutional ethical guidelines of School of Veterinary Medicine, Shiraz University for use of animals in research.

HI test: Antibody titers of all birds against AI were assayed on the day of virus inoculation followed by days 9, 14, 21 and 32 PI by HI method.

DTH test: Cell-mediated immune response was assayed by performing delayed type hypersensitivity (DTH) test as described by Munir et al. (2009) with few modifications. Fourteen days PI all birds were sensitized with $0.25 \mathrm{~mL}$ of 2, 4-dinitrochlorobenzene
(DNCB) solution $\left(10 \mathrm{mg} \mathrm{mL}^{-1}\right)$ by $\mathrm{SC}$ injection in the breast. After 14 days, these sensitized chickens were challenged with $0.25 \mathrm{~mL}$ of DNCB $\left(1.5 \mathrm{mg} \mathrm{mL}^{-1}\right)$ injected with about $2 \mathrm{~cm}$ distances on the left side of the first injection site. Skin thickness was measured at zero (defined as immediately after DNCB challenge), 24, 48 and $72 \mathrm{~h}$ post DNCB challenge by a Vernier caliper with the precision of $0.02 \mathrm{~mm}$.

Evaluation of virus shedding period: During 15 days PI samples from feces and trachea of 3 birds of each group were randomly collected with 3 days intervals and stored in $-70^{\circ} \mathrm{C}$. Virus detection was performed by Reverse Transcription-Polymerase Chain Reaction (RTPCR) method.

RNA was extracted by $\mathrm{RNX}^{\mathrm{TM}}$ (-plus) (CinnaGen Co., Tehran, Iran) commercial kit according to manufacturer's instructions. For this purpose $10 \%$ suspension of fecal samples in normal saline was prepared and after centrifugation at $7500 \mathrm{rpm}$ for 10 min in $4^{\circ} \mathrm{C}, 200 \mu \mathrm{L}$ of supernatant was used. Extracted RNA was reverse transcribed using AccuPower® RT PreMix (Bioneer Co., Daejeon, South Korea) kit. H9F and H9R primer pair which yield in specific amplification of a $488 \mathrm{bp}$ fragment within the $H 9$ gene were used with the following sequences: H9F: 5' CTY CAC ACA GAR CAC AAT GG 3' and H9R: 5' GTC ACA CTT GTT GTT GTR TC 3' as described by Lee et al. (2001) for cDNA synthesis. $5 \mu \mathrm{L}$ of the cDNA was used for PCR amplification. The PCR thermocycling condition for the gene was as follows: 30 cycles with denaturation at $95^{\circ} \mathrm{C}$ for $60 \mathrm{sec}$, primer annealing at $53^{\circ} \mathrm{C}$ for $60 \mathrm{sec}$ and primer extension at $72^{\circ} \mathrm{C}$ for $60 \mathrm{sec}$ and a final extension step at $72^{\circ} \mathrm{C}$ for 10 min (Tajmanesh et al., 2006). $5 \mu \mathrm{L}$ of PCR product was subjected to $1 \%$ agarose gel electrophoresis containing ethidium bromide and visualized under ultraviolet light.

Statistical analysis: Data were presented as mean \pm SD. Data analysis was carried out by using one-way ANOVA and Tukey's multiple comparison tests as the post hoc (SPSS 11.5 for windows software). Differences were considered significant at $\mathrm{p}<0.05$.

\section{RESULTS}

Clinical observations: No adverse clinical manifestations or mortalities were observed in birds of all groups during the experimental period.

Humoral immune responses: Figure 1 depicts the results from the HI test. Antibody titer of birds from the control group remained very low all through the sampling period. 


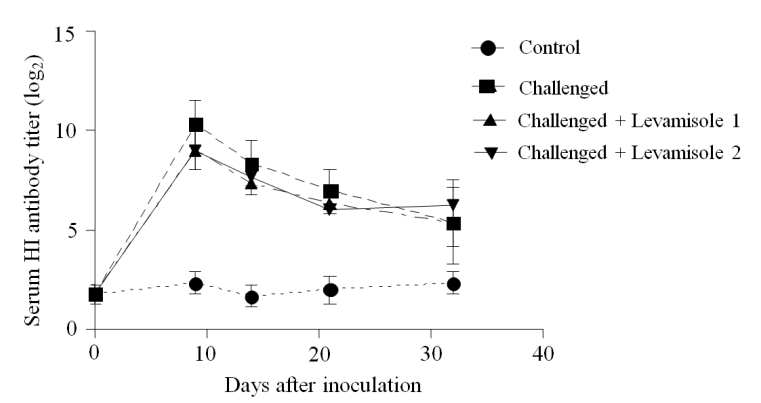

Fig. 1: HI Antibody (mean \pm SD) titers at 0, 9, 14, 21 and 32 days post inoculation of birds in different groups

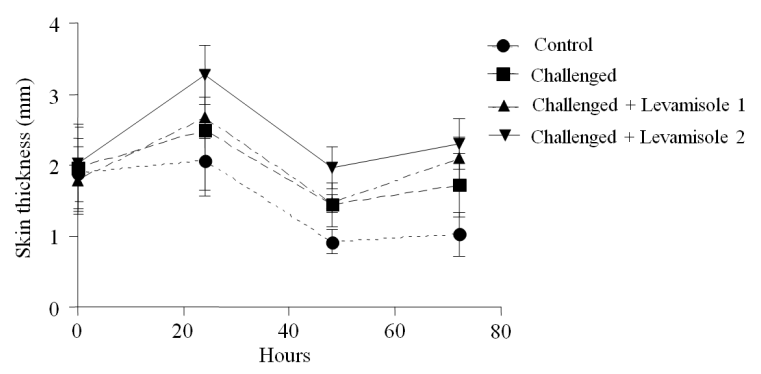

Fig. 2: Skin thickness (mean \pm SD) of birds in different groups, measured at 0,24, 48 and 72 hours post delayed type hypersensitivity test

Table1: Comparison of viral detection in feces and trachea of Japanese quails in different groups during days post inoculation (PI)

\begin{tabular}{lllllllll}
\hline \multicolumn{3}{l}{ Samples } & Feces & \multicolumn{7}{l}{ Trachea } \\
\hline Days PI & Co & Ch & Ch+L1 & Ch+L2 & Co & Ch & Ch+L1 & Ch+L2 \\
\hline 3 & $0 / 3$ & $2 / 3$ & $1 / 3$ & $1 / 3$ & $0 / 3$ & $2 / 3$ & $0 / 3$ & $0 / 3$ \\
6 & $0 / 3$ & $2 / 3$ & $1 / 3$ & $1 / 3$ & $0 / 3$ & $3 / 3$ & $0 / 3$ & $0 / 3$ \\
9 & $0 / 3$ & $2 / 3$ & $1 / 3$ & $1 / 3$ & $0 / 3$ & $3 / 3$ & $3 / 3$ & $2 / 3$ \\
12 & $0 / 3$ & $2 / 3$ & $1 / 3$ & $0 / 3$ & $0 / 3$ & $2 / 3$ & $2 / 3$ & $2 / 3$ \\
15 & $0 / 3$ & $1 / 3$ & $0 / 3$ & $0 / 3$ & $0 / 3$ & $1 / 3$ & $1 / 3$ & $0 / 3$ \\
\hline
\end{tabular}

Data presented as number of samples positive for virus/number of total samples. Co: Control; Ch: Challenged with H9N2 influenza virus; $\mathrm{Ch}+\mathrm{L} 1$ : Challenged with $\mathrm{H} 9 \mathrm{~N} 2$ influenza virus and treated with $15 \mathrm{mg} \mathrm{kg}^{-1}$ levamisole for three consecutive days just before virus inoculation and $\mathrm{Ch}+\mathrm{L} 2$ : Challenged with $\mathrm{H} 9 \mathrm{~N} 2$ influenza virus and treated with $15 \mathrm{mg} \mathrm{kg}^{-1}$ levamisole for three consecutive days just before virus inoculation which was repeated 10 days PI.

Highest antibody titer was observed 9 days post challenge in all other groups. HI titers of birds in groups 2, 3 and 4 were significantly higher than control group from day 9 and so on with $\mathrm{p}<0.02$ for all comparisons. Levamisole administration in both regimens had no appreciable effect on antibody titers during the sampling period as compared to birds in group $2(\mathrm{p}>0.05)$.

Cell-mediated immune responses: The highest skin thickness of all groups was observed $24 \mathrm{~h}$ post challenge with DNCB. Skin thickness of birds in group 2 was significantly higher than control group at 48 and $72 \mathrm{~h}$ post challenge $(\mathrm{p}=0.012$ and $\mathrm{p}=0.009$ respectively); Levamisole administration in repeated regimen (group 4) resulted in skin thickness significantly higher than group 2 at 48 and $72 \mathrm{~h}$ (p = 0.011 and $\mathrm{p}=0.031$ respectively). The difference in skin thickness of two levamisole treated groups was significant at $48 \mathrm{~h}$ with $\mathrm{p}=0.043$. Results are depicted in Fig. 2.

Virus shedding period: All samples from control group were void of virus during the whole sampling period, while both tracheal and fecal samples from group 2 became positive for virus from day 3 post inoculation and so on. $60 \%$ of total fecal samples from group 2 were positive for virus while in birds treated with levamisole the percentage reduced to 26.6 and $20 \%$ in groups 3 and 4 (34.4 and $40 \%$ lower than group 2 respectively). For tracheal samples the percentage was $73.3 \%$ in group $2,40 \%$ in group 3 and $26.6 \%$ in group $4(33.3 \%$ and $46.7 \%$ lower than group 2 respectively). Results of PCR test on fecal and tracheal samples are summarized in Table 1.

\section{DISCUSSION}

Levamisole is a synthetic anthelmintic agent with immunomodulatory properties. Its use as an immunostimulant in avian species dates back to 1979 when Soppi et al. (1979) demonstrated that levamisole is able to enhance both humoral and cellular immune responses in normal chickens. The effect was probably mediated by the activation of the $\mathrm{T}$ cell function and included only antibody responses to thymus dependent antigen. To our knowledge, although effects of levamisole on immune responses against influenza have been evaluated in humans (Obrosova-Serova et al., 1984; Pike et al., 1977) and chickens (Mayahi et al., 2007), quails were not addressed before. This motivated us to evaluate the effect of levamisole on CMI, antibody responses and virus shedding period of H9N2 AI viruses in this species with regard to the recent progressive interest in quail industry and the potential of this species as an intermediate host for both avian and human influenza viruses (Wan and Perez, 2006) accompanied by incomplete protection of inactivated vaccines (Ebrahimi et al., 2011).

Infection with AI viruses elicits a humoral antibody response at both systemic and mucosal levels. Antibodies against the surface proteins (HA and NA) are neutralizing and protective (Suarez and SchultzCherry, 2000). In our study inoculation of H9N2 virus resulted in an obvious antibody response as compared to non infected birds, which clearly 
demonstrate that inoculation of virus was successful and birds were infected.

In a study performed by Obrosova-Serova et al. (1984) levamisole activated antibody production in young subjects in response to administration of a live influenza A (H3N2) vaccine and enhanced the protective effect of vaccination. The senile subjects vaccinated with inactivated influenza A vaccine (H3N2 and $\mathrm{H} 1 \mathrm{~N} 1$ ) had a good immune response and the use of levamisole was not reflected in antibody rises. Mayahi et al. (2007) showed that daily administration of $2 \mathrm{mg}$ levamisole from two days before vaccination of chickens with killed H9N2 influenza vaccine, or $4 \mathrm{mg}$ levamisole at the time of vaccination against influenza disease can increase influenza antibody titer in this species. This is inconsistent with our results where levamisole administration in both regimens had no appreciable effect on antibody titers during the sampling period.

To describe the discrepancy, it should be mentioned that the intensity of antibody response varies with species where quails produce lower antibody responses than chickens (Davison et al., 1996; Suarez and Schultz-Cherry, 2000), this may partially describe lack of an enhanced antibody response to levamisole in our study, although the precise effect of levamisole on antibody producing cells in quails needs to be further investigated.

The host immunity, especially cell mediated immunity, is important in the pathogenesis of AI viruses. In the present study, levamisole administration at repeated regimen significantly enhanced DTH responses in quails; moreover, virus shedding was influenced. Fewer fecal samples of birds treated with levamisole were positive for virus and these samples (especially from birds treated repeatedly) became void of virus earlier than birds in group 2. Tracheal samples of birds treated with levamisole remained virus free until day 9 PI and birds treated with levamisole repeatedly, became virus negative earlier that group 2 .

Levamisole activates macrophages and enhances production of the key cytokine IFN- $\gamma$ which leads to stimulation of maturation of cells which are involved in CMI (Symoens and Rosenthal, 1977; Szeto et al., 2000). Pike et al. (1977) suggested that levamisole may be useful in enhancing depressed cellular immune function in patients with acute influenza. More over; Consistent with our results, in a study performed by Kwon et al. (2008), treating H9N2 infected chickens with cyclosporin $\mathrm{A}$, as a suppressor of $\mathrm{CMI}$ such as CD8+ T-cells and expression of IFN- $\gamma$ mRNA, was correlated with high viral load in the oropharynx and cloaca of these birds which suggests that T-cell- mediated responses is important in influenza viral clearance. More definitive tests for evaluation of CMI are needed to clarify how levamisole affects these responses and shedding of H9N2 AI virus in quails.

\section{CONCLUSION}

In conclusion, levamisole administration in a repeated regimen enhances CMI responses against H9N2 AI viruses and reduces virus shedding period in experimentally infected quails. This may pave the road for further investigations on potential positive effects of this agent on prevention and management of H9N2 AI infections in quail industry.

\section{ACKNOWLEDGEMENT}

Funding for this study was provided by Shiraz University, School of Veterinary Medicine.

\section{REFERENCES}

Alexander, D.J., 2000. A review of avian influenza in different bird species. Vet. Microbiol., 74: 3-13. DOI: 10.1016/S0378-1135(00)00160-7

Davison, T.F., T.R. Morris, L.N. Payne, 1996. Poultry Immunology, Davison. 1st Edn., Carfax Publishing Compagny, Abingdon, ISBN-10: 0902879707, pp: 463.

Ebrahimi, S.M., S. Ziapour, M. Tebianian, M. Dabaghian and M. Mohammadi, 2011. Study of infection with an Iranian field-isolated H9N2 avian influenza virus in vaccinated and unvaccinated Japanese quail. Avi. Dis., 55:195-200. PMID: 21793433

Giambrone, J.J. and P.H. Klesius, 1985. Effect of levamisole on the response of broilers to coccidiosis vaccination. Poult. Sci., 64: 1083-1089. PMID: 4011551

Kodama, H., T. Mikami and H. Izawa, 1980. Effects of levamisole on pathogenesis of Marek's disease. J. Natl. Cancer. Inst., 65:155-159. PMID: 6248672

Kwon, J.S., H.J. Lee, D.H. Lee, Y.J. Lee and I.P. Mo et al., 2008. Immune responses and pathogenesis in immunocompromised chickens in response to infection with the H9N2 low pathogenic avian influenza virus. Virus Res., 133:187-94. PMID: 18276028

Lee, M.S., P.C. Chang, J.H. Shien, M.C. Cheng and H.K. Shieh, 2001. Identification and subtyping of avian influenza viruses by reverse transcriptionPCR. J. Virol. Methods, 97: 13-22.

Mayahi, M., M.R.S. Shapouri and F. Talazadeh, 2007. Effect of levamisole administration on humoral immune response against influenza vaccine in broiler chickens. Sci. Res. Iranian Vet. J., 3: 89-94. 
Munir, K., M.A. Muneer, A. Tiwari, E. Masaoud and R.M. Chaudhry, 2009. Effects of salinomycin on cell-mediated immunity of broiler chickens against hydropericardium syndrome and Newcastle disease viruses. Poultry Sci., 88: 86-91. DOI: 10.3382/ps.2008-00345

Nili, H. and K. Asasi, 2003. Avian influenza (H9N2) outbreak in Iran. Avian Dis., 47: 828-831.

Obrosova-Serova, N.P., E.I. Schastnyi, L.M. Kupriashina, A.N. Slepushkin and S.F. Shenderovich, 1984. Immunomodulating action of levamisole in its combined use with influenza vaccines. Vopr. Virusol., 29: 454-459.

Onaga, H., M. Tajima and T. Ishii, 1984. Effect of levamisole on the immune response of chickens to infection with Eimeria tenella. Zentralbl. Bakteriol. Mikrobiol. Hyg. A., 256: 323-327. PMID: 6375211

Peiris, J.S., Y. Guan, D. Markwell, P. Ghose, R.G. Webster and K.F. Shortridge, 2001. Cocirculation of avian H9N2 and contemporary "human" H3N2 influenza a viruses in pigs in southeastern China: potential for genetic reassortment? J. Virol., 75: 9679-9686. PMID: 11559800

Pike, M.C., C.A. Daniels and R. Snyderman, 1977. Influenza-induced depression of monocyte chemotaxis: Reversal by levamisole. Cell. Immunol. 32: 234-238. DOI: 10.1016/0008-8749(77)90198-8

Reed, L.J. and H. Muench, 1937. A simple method of estimating fifty per cent endpoints. Am. J. Hyg., 27: 493-497.

Singh, K.C.P. and R.G. Dhawedkar, 1993. Immunomodulating effects of levamisole in chicks immunocompromised by infectious bursal disease virus. Trop. Anim. Health Prod., 25: 11-14. DOI: 10.1007/BF02236879
Soppi, E., O. Lassila, M.K. Viljanen, O.P. Lehtonen and J. Eskola, 1979. In vivo effect of levamisole on cellular and humoral immunity in normal chickens. Clin. Exp. Immunol., 38: 609-614. PMCID: PMC1537923

Suarez, D.L. and S. Schultz-Cherry, 2000. Immunology of avian influenza virus: A review. Dev. Comp. Immunol., 24: 269-283. PMID: 10717293

Symoens, J. and M. Rosenthal, 1977. Levamisole in the modulation of the immune response: The current experimental and clinical state. J. Reticuloendothel. Soc., 21: 175-221. PMID: 142150

Szeto, C.C., K.M. Gillespie and P.W. Mathieson, 2000. Levamisole induces interleukin-18 and shifts type 1/type 2 cytokine balance. Immunology, 100: 217224. DOI: 10.1046/j.1365-2567.2000.00042.x

Tajmanesh, S., R. Toroghi, R. Momayez and S.A. Pourbakhsh, 2006. Establishment of RT-PCR for detection of avian influenza virus (H9N2) in field cases compared to virus isolation method. Arch. Razi Inst., 61: 111-116.

Tang, X.Y., G.B. Tian, C.S. Zhao, J.F. Zhou and K.Z. $\mathrm{Yu}$, 1998. Isolation and characterization of prevalent strains of avian influenza viruses in China. Chin. J. Prev. Vet. Med., 1: 1-5.

Wan, H. and D.R. Perez, 2006. Quail carry sialic acid receptors compatible with binding of avian and human influenza viruses. Virology, 346: 278-86. DOI: 10.1016/j.virol.2005.10.035

Yin, J., H. Jin, F. Yang, Z. Ding and C. Huang et al., 2007. Synergistic effects of adjuvants interferongamma and levamisole on DNA vaccination against infection with Newcastle disease virus. Viral Immunol., 20: 288-299. PMID: 17603845. 